\title{
coX11 wt Allele
}

National Cancer Institute

\section{Source}

National Cancer Institute. COX11 wt Allele. NCI Thesaurus. Code C90143.

Human COX11 wild-type allele is located in the vicinity of $17 q 22$ and is approximately 17 $\mathrm{kb}$ in length. This allele, which encodes cytochrome c oxidase assembly protein COX11, mitochondrial protein, plays a role in the regulation of cytochrome c oxidation. Single nucleotide polymorphisms in the gene may contribute to breast cancer susceptibility. 